\title{
Should We Be Worried about the Increasing Foreign Ownership of UK Industries?
}

\author{
David Floyd1, Barry Ardley¹, Sandhla Summan², Mizan Rahman1, Dimitrios Vortelinos ${ }^{*}$ \\ ${ }^{1}$ Lincoln Business School, University of Lincoln, Lincoln, UK \\ ${ }^{2}$ Lincoln Law School, University of Lincoln, Lincoln, UK \\ Email: *dvortelinos@lincoln.ac.uk
}

Received 9 February 2016; accepted 8 April 2016; published 11 April 2016

Copyright (C) 2016 by authors and Scientific Research Publishing Inc.

This work is licensed under the Creative Commons Attribution International License (CC BY).

http://creativecommons.org/licenses/by/4.0/

(c) (i) Open Access

\begin{abstract}
Should we be more concerned about the foreign ownership of UK Brands? Is Britain making the most of its industrial brands? Much has been made of these questions and the recent contracting out of nuclear energy to China. This is only one of several examples of recent contracting out of activity. Indeed most rail franchises are now foreign owned and most electricity providers are also from mainland Europe. The process of selling off much industry has been taking place in the UK for many years and it has now gone much further than merely selling off the family silver. Recently in the House of Commons mention was made of the time that has now arrived to sell the fixtures and fittings. This paper sets out to explain the reasons why the UK has been willing to sell off many historic firms and assesses the consequences of this for future generations. The paper draws on theories of international marketing, corporate strategy and production to help explain the relevant thinking behind current policies. It also draws on case examples, relevant theory and data, in order to provide further evidence for future policy making, arguing that it still vitally important for the UK to undertake the strategic stewardship of its remaining brands.
\end{abstract}

\section{Keywords}

Corporate Strategy, Ownership, Contracting, UK Brands, Marketing

\section{Introduction}

The UK has always adopted a more liberal attitude towards markets, particularly from the 1980s period where privatisation was championed by the Thatcher government. Gradually more foreign firms began to take over British brands particularly in the car industry including BMW, Honda and their involvement with the Rover car

"Corresponding author.

How to cite this paper: Floyd, D., Ardley, B., Summan, S., Rahman, M. and Vortelinos, D. (2016) Should We Be Worried about the Increasing Foreign Ownership of UK Industries? Theoretical Economics Letters, 6, 178-185.

http://dx.doi.org/10.4236/tel.2016.62020 
company. More lately, Tata Motors of India have taken over Jaguar; Chinese firms such as Geely have merged with Volvo and Chinese firms are also involved with MG and the UK Taxi making business. In trucks and van production Daf took over Leyland trucks and Volvo have taken over much of the former Leyland Bus company. There has also been the involvement of Malaysian firms in UK racing car brands and the takeover of Rolls Royce cars by the German firm BMW. Interestingly, some of these firms have kept the brand name despite the change in ownership. Even more recently a Chinese firm is now preparing a bid to take over bus manufacturer Alexander Dennis. This situation has not occurred so much in France where the French government has been more willing to step into, even though here Renault and Nissan are sharing platforms. Much of the reasons for foreign takeover of car producers in the UK put forward have been related to lack of investment and loss making activity. The benefits of free markets have been championed where the consumer gets more choice and better quality when all firms have access to UK markets and takeover bids; see Floyd 1997 [1], Bishop 1995 [2]. Indeed Lord Desai 2015 suggested that the UK car industry was completely saved by the influence of Foreign Direct Investment.

In terms of penetration of ownership, in railway franchising, most is foreign owned and electricity and gas suppliers are mostly from France and Germany. In telecoms, French and German firms have a strong position in the UK. The European Single market has been pushed by the EU whereby any public contract over 400,000 Euros should be open to European tender and published in a European Journal; see Dearden [3]. However in France and Germany and many other countries there is much less choice in suppliers; see European Union White Paper on Energy 2014 [4]. Furthermore in France, the large engineering firm Alstrom was not allowed to be taken over by Siemens and this suggests that there is a different attitude to traditional brands in different countries despite a free market existing, in theory. It is also doubtful whether the French government would allow Chinese involvement in the nuclear sector as has been the case recently in the UK. Even in USA the government has prevented the telecoms firm Huawei from entering the US market; see Floyd et al. [5]. In terms of the UK's more open policy however, a major difficulty exists. The broad problem is, where does a liberalised state of affairs, in terms of acquisition, leave those brands that still remain under UK ownership? After considering some issues around the foreign ownership of previous home based brand assets, the main focus of this paper is to then argue that the UK government must ensure a strong stewardship of the brands that remain genuinely "home owned", occurs. This should become a main strategic initiative. Without this taking place, home consumer demand for some brands may diminish, but perhaps more importantly, a source of key competitive advantage, the "Made In" label will be lost and all its attendant problems will surface for the UK. At stake here is the ability of a country to compete effectively on a global stage, and attract investment and income, these are the key factors we argue that need much more consideration.

\section{The Case for Foreign Ownership}

Many theorists including Dunning 1993 [6] have championed the benefits of foreign investment. Today over 40\% of UK output is attributed to foreign firms and the globalisation process. For example, foreign firms can bring in new skill sets and job opportunities through supplier linkages. Entrepreneurship can be increased in order to supply the foreign firm. Additional competition can help spur innovation in local firms and help firms to become more efficient and improve their product range. Porter 1990 [7] suggests a nations factor conditions can therefore be improved. Trade and improvements can be made in the balance of payments, for example Britain is now a net exporter of cars despite many of the large manufacturers being foreign owned. In the case of Jaguar the old brand has remained despite having a different ownership. In the aviation industry the UK benefits from both Airbus and Boeing winning new contracts due to the presence of both companies. Former Trade Minister Lord Digby Jones 2016 suggests that the Sunderland car plant is the most productive in Europe and has a foreign owner. The UK makes more parts for the Airbus in Toulouse than either France or Germany. General Motors is also closing a car Plant in Germany whilst expanding in the UK. Foreign ownership can also help government save money in supporting industry and therefore more money could be available for other services such as healthcare provision, indeed this sector is also one of the major strengths of the UK economy. The various takeovers of British firms has also led to more business activity for the UK financial sector and therefore providing a strong boost for this internationally. It may also have led to a stronger currency which may have influenced the level of exports and the competitive nature of the UK economy. Indeed, the UK was successfully globally in financial trade a long time before success as a manufacturing exporter. More recently society in the UK and many 
other countries has become increasingly globalised and smaller amounts of the population are recalling historic British brands, see Farnham 2015 [8]. However, there are some key arguments we begin to address from the next section onwards, that suggest Britain should be careful in this approach and nor cede all its brands to overseas companies. Further, we argue the UK government should adopt a strategic focus towards country of origin branding, subsequently facilitating the opportunity to create competitive advantage and differentiation not only for the brands in question, but for the country itself.

\section{How Concrete Are the Arguments for Maintaining the Current Levels of Ownership of UK Brands?}

Much of the case for firms to remain in British hands could be linked to identity and patriotism. In some sectors governments over the past have invested large amounts of money in redevelopment and it may be a shame in some cases to have this passed on to predator firms that may in the long term only keep a small amount of the company and mainly just keep the brand but conduct the manufacturing and research process mainly overseas. Recently the government is looking to improve the tax incentives for banks in order to keep the HSBC headquarters in the UK. However, this approach has not been adopted for the case of many manufacturing firms. There is also the argument that we should keep strategic industries in our own hands, as often foreign firms may cut jobs in the UK first to protect their own home nations. There is an interesting case of Nissan UK with the most productive factory in Europe. The company is now facing the prospects of more jobs going to France where its French partner Renault is based, see The Times December $3^{\text {rd }} 2015$ [9]. In addition, the steel industry has had much involvement from Indian and Thai based companies and the higher exchange rate has led to large job losses here. Krugman [10] suggests many arguments for protectionism, where funding from national governments can lead to successful outcomes in terms of new technology. The aeronautical industry proves to have some useful examples in this regard.

It has also been shown that a manufacturing recovery may be the best way to sustain a long lasting recovery rather than relying on unsustainable consumer credit based booms. Many authors such as Pearce [11] have also suggested that foreign firms may be more likely to abuse the tax regime due to less commitment to the foreign location, Starbucks provides a useful example in this respect. More recently Cadbury, that was taken over by Kraft has reduced its workforce in the UK and been accused of shifting some of its tax liabilities overseas. In line with the position raised in the introduction to this paper, marketing theory also suggests there are additional benefits to be achieved from holding on to key brands. Here, the notion of country of origin and its importance will be examined and the economic implications analysed.

\section{The Implications of Country of Origin Branding for Global Consumers and Home Markets}

Firstly some brief background. Historically, Schooler [12] and Reierson [13] are often viewed as the initiators of the stream of work on country of origin effects. Their prime purpose was to determine whether or not a relationship exists between country of origin (COO) and brand and product image. In step with the increasing amount of global expansion strategies by firms around the world, a considerable amount of literature has been developed which considers the impact of country of origin labelson consumer product evaluations [14]-[16]. This area of $\mathrm{COO}$ represents the additional dimension to the debate that could have potentially damaging consequences for brands stewardship, if not properly managed from a UK perspective. A key driver here is globalisation, allowing consumers across the world to access similar products, whenever they might reside. A factor impacting on the demand for products originating from other than the home country is the point that COO perception is likely to be effected by consumer interpretations of the political and cultural belief systems of the products and brands origin, in comparison to their own country [15]. Further, deMooij [17] points out that customers from the same country have very similar perceptions, as most nations develop historically in a holistic fashion, sharing usually, one dominate language, mass media infrastructure, education system and national product markets. It is not unreasonable to argue then, that the nature of consumer's national backgrounds influence strongly their perception towards country of origin of products and brands. According to Al-Sulaiti and Baker [18], COO effects remain the most researched among the many factors believed to influence consumer brand responses in an age of global competition.

One strand of research in the area, shows that $\mathrm{COO}$ effects of a product have been found to influence con- 
sumer evaluations of the product on the key dimensions of quality and purchase value [19] [20]. Here, COO is used by consumers to predict quality and performance of the products they might buy [21]. Other approaches have attempted to explain the socio-psychological process of COO effects through the halo effect model [22]. In this case, when consumers are not familiar with the products of a country, COO information acts as a "halo" that impacts directly on consumer beliefs about a product. The image of the country itself might be generated from consumer experiences, knowledge about the country, political beliefs or ethnocentric tendencies. Stereotypes can have a role to play here, alongside emotions that assist consumers in forming impressions. Significantly, research by Chattalas et al. [23], demonstrate that that customer perceptions towards country of origin are more likely to be of the stereotype variety, than anything else. Important differences can exist then between consumer's perceptions of countries and the products that come from them.

The notion of a "refusal of other tastes" [24] also suggests that negative stereotypes might emerge about COO. A problem can be that if too many brands are physically relocated to places or are acquired by owners from countries that have negative images or indifferent views about them, then consumer confidence and sales could be adversely affected. Even, potentially, a positive image associated with COO could result in negative perceptions of home industries, if UK brands get taken over by countries that exhibit very positive stereotypes. For example, the takeover of UK engineering companies by German based firms. Germany is perceived as having a favourable conjunction between its country image and products [25]. The notion of "image crystallisation" linking brand image to country image might paradoxically mean in some cases, that some global consumers end up with very negative views about a countries apparent lack of industrial capability, if they see UK firms being rescued constantly, or being simply taken over, by overseas brand owners. This could very well impact on the demand for UK good generally. Consequently, COO effects can have a potential significant impact on not only on consumer perceptions, but also on the wider economic performance of a country.

\section{The Brand Equity and Country of Origin Relationship}

Usually then, $\mathrm{COO}$ is regarded as an asset when it is positive and a liability when it is negative [26]. One useful way to indicate the importance of country of origin image is to see it as an expression of the equity a brand holds, in terms of the perceptions of end users or anyone i.e. another stakeholder, who comes into contact with the brand, see Figure 1 below. Aaker [27] recognised as a leading exponent of brand management, suggests brand equity is composed of five key components. These consist of consumer awareness, consumer associations, perceived quality and loyalty, which results in a willingness to pay a price differential. Finally, any other proprietary assets connected to the brand can be viewed as either assets or liabilities. A great deal of work on brand equity points in this general direction [28] [29]. Importantly, it is brand associations that can be linked to country of origin image and if the UK continues to lose brands to foreign owners-and depending on whom these foreign owners are-it could mean that these brands end up acquiring negative connotations, not only from UK consumers, but in overseas markets as well. Crucially COO is routinely communicated by "made in" or "manufactured in" labels, which are prominently displayed [26] [30]. This further underscores the image of a product and the country it comes from, in a consumer's mind, thus influencing the equity standing of the brand [31].

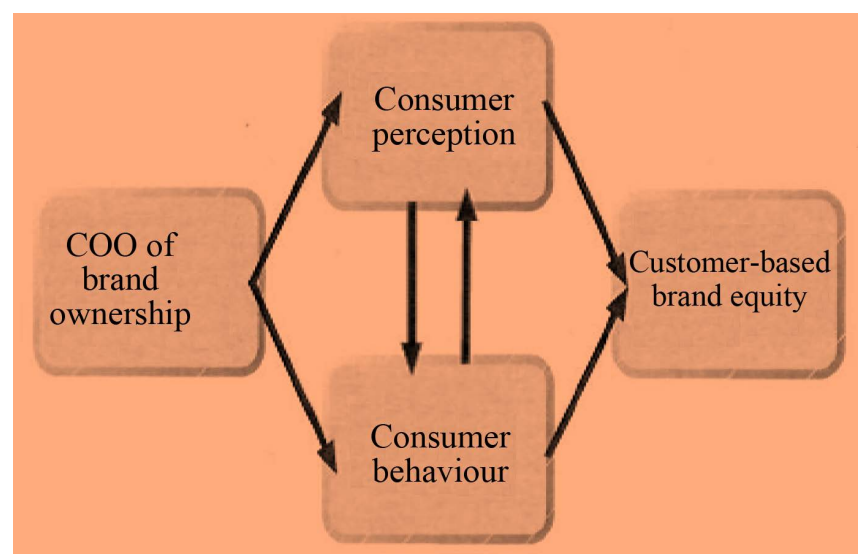

Figure 1. Country or origin and the brand equity relationship. 
A graphic illustration of the importance of $\mathrm{COO}$ exists with regard to Burberry. Whilst we recognise that Burberrys is a UK brand, the switching of some production to China caused the company significant problems [32]. "Made in the UK" suddenly no longer applied in the same way and a range of negative connotations began to be applied to the famous brand. The brand became associated with poor working conditions, a less developed economy, generally unethical practices and a degree of unscrupulous foreign control. After moving part of its operations, Burberrys revenues and share prices dropped significantly and city stakeholders in the UK, forced the company to bring its production processes back. Consumer based brand equity value and the financial equity, dropped in overseas markets as well as at home. Relatedly, some research has indicated that consumers regard advanced countries workers as more capable of making quality products than those in developing countries [33]. This is a factor additionally compounding the problem faced by Burberry, despite China's positive economic surges in recent decades. An additional problem is that it is not only other countries consumers who might start to hold negative views about the brand. Home demand for products, with the wider implications for economic activity, can also potentially drop, if adverse or equivocal views are held about UK brands. The furore surrounding the takeover of Cadburys in the UK, by overseas owners, elicited very strong emotions about the loss of an iconic UK brand. In this case and others, culturally determined emotional responses [29], are likely to impact on consumer perceptions of the brand and the company which has been taken over. That consumers can be largely ethnocentric in behaviour, perhaps due to an increasing awareness of the global condition, might actually means that localisation in terms of the keeping of brands under home ownership, become more important than ever. The very nature of consumer identity can, in this sense, be linked to their home country.

\section{Brands and Country of Origin Advantage: The Economic Dimension}

It is clear that country of origin is a key initiator of every day consumer choice and can therefore directly impact on Gross Domestic Product by creating revenues through the sale of products both at home and abroad. Critically, consumers can enjoy a country of origin brand without having to visit the location. There are two key issues here. Firstly consumers can buy a little bit of the UK and what it stands for when for example, they purchase a Morgan sports car. This is significant because brand driven consumption is increasing with the growth of new middle class consumers in the BRIC markets, China and other developing nations [26]. There are now more middle class consumers in China, than in the entire population of Europe. These new consumers are exercising their recently acquired power through brand driven consumption. Secondly, given this scenario, brands are now capable of reaching more new consumers in more places more often than any other drivers of country reputation and association. The implication of this is that a clearer' made in' story across design, manufacturing and marketing will mean that a positive country of origin effect will start to contribute very significantly to national reputation, income and investment and to the overall strength of that country as a brand in itself. The UK brands in question, then becomes an asset not just for UK brand owners, but also for the home country as well. Currently, the UK does not figure high on global consumer's perceptions of choice; ranked overall first and second are the USA and France [26]. The Made in becomes not just a mantra, but a legal and marketing asset that needs to be protected so that UK brands have a basis from which to prosper and develop.

An added problem here is that in the UK, the government must be alert to the rise of origin brands from counties previously not concerned with this phenomenon. For example, it is possible that China which has traditionally assembled goods and supplied them for other manufacturers [34] will start to design and perhaps more importantly, market goods that represent real alternatives to those found in UK markets. The rise of technology brands like Huawei, with its huge home market as a springboard for growth, is a case in point. This means real economic competition. Consequently, the UK needs to invest in its brands and support approaches to this process so that a very clear made in the UK story emerges and is then established for the longer term. Furthermore this is not a one off issue. Brands cannot be seen as static resources either by a firm or a government. Entrepreneurial approaches to the management of brands in terms of either incremental or discontinuous innovation should be undertaken and entrepreneurially based marketing approaches can contribute significantly to the wealth creation process in a country, as pointed out Schindehutte, et al. [35]. In addition, the stretching of brands in different directions with new lines canarguably create significant consumer interest around the globe, as customers seek out novel experiences and innovations in their relationships with brands from particular countries.

\section{Brands and Country of Origin Advantage: The Regulatory Dimension}

In respect of supporting a country brands, it is worth discussing here the contribution of Andersen and Poulfelt 
[36], who point out the role of the regulatory dimension in promoting successful companies and their brands. Clearly regulatory approval, support and tolerance differ markedly from country to country, as does each countries eagerness to support its own domestic firms. The authors argue that in terms of context, the world economy is in a state of transition with successful companies able to exploit a new paradigm of business. Andersen and Poulfelt [36] argue that this emerging paradigm is comprised of five key dimensions. Firstly, there is the surprise dimension, where firms canenter a market as unexpected movers. This is illustrated by the example of the Indian company Aravinda, who combined a surprise market move very successfully, with another dimension, the low cost area. In this case, cataract eye surgery was united with a relatively cheap McDonalds like assembly process, which no competitor expected to happen. Thirdly, there is the innovation dimension, where companies think outside the box to deliver something original. In this dimension examples include Apple and Google, companies who can be regularly associated with the creation of new customer value, through a stream of innovative products and services [36]. Fourthly, there is the $\mathrm{x}$ factor dimension, an elusive element of strategy that cannot be anticipated. It is a noteworthy talent that is difficult to replicate or put into a conventional model. Possibly, as Andersen and Poulfelt [36] note, It can be identified with a person as much as a process, i.e., Michael Ryan and his disruptive approach to the airline industry.

Lastly, and perhaps most significant, there is the regulatory dimension. This represents the key component interms of the argument in our paper. Normally, this area is not much part of a company's business strategy, being little accounted for in literature on country of origin and brand success. Andersen and Poulfelt [36] argue however, that the regulatory dimension is in contrast, crucial to the success of brands, suggesting that the UK government should actively become involved in the support of its home brands. Andersen and Poulfelt [36] go on to point out companies can win considerable advantages, if they can gain regulatory favours from their home governments. Conventional strategy suggests however, this is best left to market forces [36]. They cite the example of Huawei, with its strong ties to the Chinese government, where there are state financed credit facilities available for the firm's customers and various interstate agreements facilitating easy advantageous access to home markets. This type of strategy represents the basis for opportunity development in global markets and given this situation, foreign firms have to work hard to gain even a foothold in an uneven market situation. Equally, as another example, Emirates' airlines have taken advantage of an ambitious Dubai national strategy, whilst in another case, Aravinda works with the Indian national government to improve its efficiency and service product quality. In Brazil, the beauty company iNatura, is in receipt of tax incentives to develop it brand [36]. While all these options might not of course be open to UK brands, some will and others need to be considered. Of critical importance, it is the principle of support available to domestic brands that is important. Policies are required to support the UK owned brands that remain. Competitively, if a UK owned firm can gain some sort of regulatory advantage from its home government, whilst other foreign competitors suffer disadvantages, then it can help to establish and grow both the home brand and the home country. The result is two income generating entities, as is the case with China and Huwaii.

\section{Conclusion: Supporting UK Brands and the Country Brand}

It is vitally important that the UK government takes a proactive stance towards the stewardship of the remaining brands under home ownership. Support is primarily needed for the remaining UK owned brands, in order for the country to meet its full potential. Taking advantage of the historical tradition and heritage of brands and the values behind them may further help to maintain a future in key manufacturing sectors. The UK will need to work at the same time, on its country brand, which can act as a halo effect on consumer products and services, thus driving demand and inward investment. Importantly it is difficult to create a brand without a story that it is not unique or does not have an authentic set of attributes, as customers can easily access information about the alternatives available. Crucially, through providing support and by understanding origin, its meaning and potential, the UK government could conceivably offer the countries' remaining brands the very real prospect of creating long term competitive advantage and differentiation, in the fierce markets represented by the current conditions of world trade. Finally, it must be remembered that across the developed and developing world, other countries and their home brands will also be adopting a similar focus by competing around the notion of "made in"; so the UK and its remaining brands, should think about acting quickly and resolutely.

\section{References}

[1] Floyd, D. (1997) UK Membership of the European Union: Establishing a Framework for Analysis. European Business 
Review, 97, 63-67. http://dx.doi.org/10.1108/09555349710162562

[2] Bishop, M. and Kay, J. (1995) The Regulatory Challenge. Oxford.

[3] Dearden, S. (2005) European Economic Integration. Pearson.

[4] European Commission (2014) Towards More Effective EU Merger Control. Whiter Paper on Energy, European Union.

[5] Floyd, D., Ardley, B. and McManus, J. (2011) Can China Overcome the Difficulties of Establishing Successful Global Brands? Strategic Change, 20, 299-306. http://dx.doi.org/10.1002/jsc.902

[6] Dunning, J. (1993) The Globalisation of Business. Routledge.

[7] Porter, M. (1990) The Competitive Advantage of Nations. Harvard Business Review, 68, 73-93. http://dx.doi.org/10.1007/978-1-349-11336-1

[8] Farnham, D. (2015) Human Resource Management and Its External Context. Chapter from Human Resource Management in Context. 3rd Edition, CIPD Publications.

[9] Lea, R. (2015) Nissan Alliance with Renault under Threat. The Times, December 3. http://www.thetimes.co.uk/tto/business/industries/engineering/article4630778.ece

[10] Krugman, P. and Obstfeld, M. (1988) International Economics: Theory and Policy. Scott Foresman/Little Brown.

[11] Pearce, R. (1992) World Product Mandates and Multinational Specialisation. Scandinavian International Business Review, 2, 38-58. http://dx.doi.org/10.1016/0962-9262(92)90020-7

[12] Schooler, R.D. (1965) Product Bias in the Central American Common Market. Journal of Marketing Research, 2, 394397. http://dx.doi.org/10.2307/3149486

[13] Reierson, C. (1966) Are Foreign Products Seen as National Stereotypes? Journal of Retailing, 42, 33-40.

[14] Johansson, J.K. (1989) Determinants and Effects of the Use of “Made in” Labels. International Marketing Review, 6, 47-58. http://dx.doi.org/10.1108/EUM0000000001502

[15] Han, C. (1990) Testing the Role of Country Image in Consumer Choice Behaviour. European Journal of Marketing, 24, 24-39. http://dx.doi.org/10.1108/EUM0000000000609

[16] Ahmed, Z.U., Johnson, J.P., Yang, X., Fatt, C.K., Teng, H.S. and Boon, L.C. (2004) Does Country of Origin Matter for Low-Involvement Products? International Marketing Review, 21, 102-120.

[17] De Mooij, M. (2005) Global Marketing and Advertising Understanding Cultural Paradoxes. Sage, London.

[18] Al-Sulaiti, K.I. and Baker, M.J. (1998) Country of Origin Effects: A Literature Review. Marketing Intelligence and Planning, 16, 150-168. http://dx.doi.org/10.1108/02634509810217309

[19] Khachaturian, J.L. and Morganosky, M.A. (1990) Quality Perceptions by Country of Origin. International Journal of Retail and Distribution Management, 18, 21-30. http://dx.doi.org/10.1108/EUM0000000002934

[20] Ahmed, S.A. and d'Astous, A. (1995) Comparison of Country of Origin Effects on Household and Organisational Buyers Product Perceptions. European Journal of Marketing, 29, 35-51. http://dx.doi.org/10.1108/03090569510145741

[21] Hamin, H. and Elliott, G. (2006) A Less Developed Country Perspective of Consumer Ethnocentrisms and "Country of Origin” Effects: Indonesian Evidence. Asia Pacific Journal of Marketing and Logistics, 18, 79-92. http://dx.doi.org/10.1108/13555850610658246

[22] Knight, G.A. and Calantone, R.J. (2000) A Flexible Model of Consumer Country-of-Origin Perceptions: A CrossCultural Investigation. International Marketing Review, 17, 127-145. http://dx.doi.org/10.1108/02651330010322615

[23] Chattalas, M., Kramer, T. and Takada, H. (2008) The Impact of National Stereotypes on the Country of Origin Effect: A Conceptual Framework. International Marketing Review, 25, 57-74. http://dx.doi.org/10.1108/02651330810851881

[24] Bourdieu, P. (1984) Distinction: A Social Critique of the Judgement of Taste. Routledge, London.

[25] Chen, H.C. and Pereira, A. (1999) Product Entry in International Markets the Effects of Country of Origin on First Mover Advantage. The Journal of Product and Brand Management, 8, 218-231. http://dx.doi.org/10.1108/10610429910272493

[26] Future Brand (2014) Made In: The Value of Country of Origin for Future Brands. Working Paper, Future Brand. http://www.futurebrand.com/images/uploads/studies/cbi/MADE_IN_Final_HR.pdf

[27] Aaker, D.A. (1991) Managing Brand Equity. Free Press, New York.

[28] Keller, K.L. (1993) Conceptualizing, Measuring, and Managing Customer-Based Brand Equity. Journal of Marketing, 57, 1-22. http://dx.doi.org/10.2307/1252054

[29] Rosenbaum-Elliott, R., Percy, L. and Pervan, S. (2015) Strategic Brand Management. Oxford University Press, Oxford.

[30] Bilkey, W. and Nes, E. (1982) Country of Origin Effects on Product Evaluations. Journal of International Business 
Studies, 8, 89-99. http://dx.doi.org/10.1057/palgrave.jibs.8490539

[31] Chapa, S., Minor, M.S. and Maldonando, C. (2006) Product Category and Origin Effects on Consumer Responses to Counterfeits: Comparing Mexico and the US. Journal of International Consumer Marketing, 18, 79-99. http://dx.doi.org/10.1300/J046v18n04_05

[32] Cadwalladr, C. (2012) The Hypocrisy of Burberrys Made in Britain Appeal. http://www.theguardian.com/commentisfree/2012/jul/16/burberry-china-british-carole-cadwalladr

[33] Li, W.K. and Monroe, K.B. (1992) The Role of Country of Origin Information on Buyers’ Product Evaluation: An In-Depth Interview Approach. Enhancing Knowledge Development, 3, 274-280.

[34] Fan, Y. (2006) The Globalisation of Chinese Brands. Marketing Intelligence and Planning, 24, 365-379. http://dx.doi.org/10.1108/02634500610672107

[35] Schindehutte, M., Pitt, L. and Morris, H. (2007) Rethinking Marketing: The Entrepreneurial Imperative. Pearson, London.

[36] Andersen, M. and Poulfelt, F. (2014) Beyond Strategy: The Impact of Next Generation Companies. Routledge, London. 